\title{
1. The one and only sovereign
}

\subsection{ONE-STATE WORLD}

Let us imagine a world with only one state. The state, Kyber, prints a paper currency called kobank (ł) that its citizens use to buy goods and services and to pay their taxes. The currency is used as a medium of exchange, unit of account and store of wealth. ${ }^{1}$ Kyber is run by a government that has many branches, such as those that deal with education, transportation and security. The fiscal authority (FA) and the monetary authority (MA), the central bank (CB), are responsible for making economic policy. Economic policy includes both domestic economic policy (DEP) and foreign economic policy (FEP), the management of a state's currency in relation to other states' currencies. In our example, though, Kyber is the only state in the entire world. Therefore, it does not have to conduct FEP - establish a price, an exchange rate (ER) - between its currency and foreign currencies. Kyber is not concerned, furthermore, that its citizens may take their assets and money, their capital, out of its territory and move them to other states. Kyber is the true one and only sovereign since it does not have to deal with other states and can keep people's wealth trapped in it.

Kyber is a market economy. In a market economy decisions are based on supply and demand dynamics - the supply of goods and services by producers and demand for goods and services by consumers. On a basic level, the supply/ demand forces work in the following way: scarcity in the supply of a good, that happens to be in high demand, drives its price up, motivating producers to ramp up production of that good. This increases its availability and, consequently, brings the price down. Abundance in the supply of a good, when combined with tepid demand, drives the price of that good down. This dispirits producers, which reduce production. The resulting scarcity brings the price of the good up, especially if demand has, in the meantime, rebounded.

A fundamental feature of this well-organized market economy are well-functioning securities markets - a stock market and a bond market. A stock market is a place where business sell and people buy stocks, shares,

1 Charles Proctor, Mann on the Legal Aspect of Money 10 (2012). 
that is units of ownership in a company. A bond market is a place where business and, as we will see below, the government, borrow. Bonds are 'I owe you' (IOU) instruments that acknowledge debt. Business issue bonds and stocks because they want to raise money from the public to create new products or improve the goods and services they offer. The government issues bonds, borrows from the public, to fix the public infrastructure or to pay for public schools and other public welfare projects. The general public is free to invest in the stock market and in the corporate and government bond markets.

The government makes its policy based on the conditions of the economy, but also on many other factors that are important for the maintenance of a peaceful polity. To simplify matters here we assume that the government is popular. However, there are minor insurgencies and terrorist acts that, from time to time, rattle the society. Major and minor natural disasters do occur. Because of the uncertain future condition of the world and, as we will see below, the structure of the financial system, the economy is vulnerable to crises. The world government tries to keep its economy strong. The gross domestic product (GDP) is a rough way to calculate the total economic activity of both the state and its people. The GDP is calculated annually and it reflects the total value of goods and services produced in the economy by the state and population. The government uses a simple formula to calculate the GDP: $\mathrm{GDP}=\mathrm{C}+\mathrm{G}+\mathrm{I}$ (where $\mathrm{C}$ stands for private consumption, $\mathrm{G}$ for government spending and I for all investment in the economy - public and private). When GDP is up, it means that the economy is growing. When GDP is stagnant or decreasing, it means that the economy may be in trouble or even in recession. When a recession is prolonged and severe, the economy is in depression.

All through its life span, the state has faced a number of economic conditions: rapid growth, slow growth, recessions and depressions. Periods of rapid economic growth are usually characterized by price inflation while recessions are accentuated by deflation. This makes intuitive sense. High economic growth means high consumption and investment. If increasing consumption and investment are not matched by the increasing production of goods and services, the outcome will be inflation, an accelerating increase in prices. On the contrary, recessions are marked by low consumption and investment. If, during an economic downturn, producers continue to produce as many goods as they did before, the weak demand for those goods will cause deflation, a decrease in prices, and the economy will eventually enter into recession.

Inflation can be caused by many factors, such as a shortage of basic supplies, the resources that are needed to run the economy - a supply shock. For instance, an unexpected shortage in the supply of oil, owing to sabotage by a group of people, may trigger unexpected inflation. Given the oil shortage, oil companies will have to bid against each other for the limited oil output, triggering a spike in oil prices. As oil suppliers increase their prices, producers 
of other goods, whose production depends on oil, will have to increase their prices as well. If most economic production depends on oil, most businesses will resort to price increases. As the prices of products and services increase, employees, who are also consumers, will have to ask for higher wages. Unless the oil supply quickly bounces back to its prior level, expectations of continuing rising prices can trigger accelerating inflation and possibly hyperinflation.

Inflation can be caused also by the scarcity of human labor. When GDP is up and businesses are booming, they are prone to hire people to help them boost their production. When too many businesses bid for too few laborers, wages increase. Businesses, in turn, pass the higher labor costs to consumers by increasing the prices of goods they sell. Higher prices generate demands for higher wages - the vicious circle of inflation.

Accelerating inflation can have a corrosive effect on an economy. As people need more and more money to buy goods, services and assets, the currency gradually loses its value. Kyber does not want people to lose faith in the value of its currency. If people start to view the kobank as something no better than a piece of paper, they will be likely to discard it and establish another means of exchange (such as barter, gold or an underground crypto-currency). When a currency is not associated with something deemed to have lasting value (e.g. gold), its worth is measured by the confidence of the public in the state that issues the currency. Loss of faith in a currency means loss of trust in the state that prints that currency. In fact, there is no surer means of sabotaging a state than debauching its currency. ${ }^{2}$

Recessions are an anathema to states as much as uncontrollable inflation. Recessions are often caused by unpredictable events and catastrophes. During recessions many businesses lose money. As a result, they fire workers or stop hiring. People who are laid off are unlikely to find new jobs in a recessionary economy. Many may resolve to live in poverty or resort to petty crime. When recessionary conditions last long, it is hard to get the economy back on the growth path. As companies lay off workers, private consumption and investment decrease. This reduces further corporate profits and spurs more layoffs. An economic recession can, thus, turn quickly into depression. A chronic depression can create a fertile ground for revolt. Chronic depressions undermine the authority of the sovereign as they lay bare its inability to provide the conditions that would help people prosper.

2 Paraphrasing Keynes, see John Maynard Keynes, The Economic Consequences of the Peace 139 (1920, reprinted in 2013 by Keynes Press). 


\subsubsection{Basic Economic Functions}

The FA, called also Finance Ministry or Treasury, decides how much to spend and to collect in taxes. By doing so, it determines how much money people have at their disposal. The more the taxes the FA collects, for instance, the less money people have. The more it spends - by paying government employees or companies that build the public infrastructure - the higher the money, the liquidity, in the economy. The FA may decide to deal with the distribution of money. It may tax the rich and direct the money it collects from them to the poor. In this book, we do not deal with the distributional aspects of fiscal policy. We focus, instead, on how decisions of a government to tax, spend and, as we will see below, borrow affect the total amount of money in the economy.

The government tries to keep the economy growing at a sustainable rate to avoid the adverse effects of uncontrollable inflation or deflation. The role of the MA is to figure out what that growth rate is and use its toolkit to keep the economy growing at that rate. We can think of the MA, the $\mathrm{CB}$, as the economy's primary assessor and regulator. The CB has concluded, after repeated trials and errors, that a $2 \%$ yearly inflation is the magic number that keeps the economy growing at a sustainable growth rate. The $\mathrm{CB}$ has determined that when inflation fluctuates around 2\%, almost all people (Box 1.1) who are capable and willing to work can find gainful employment. This eliminates the risk that shortages of labor will trigger wage increases and, in turn, price increases. The $\mathrm{CB}$ has the flexibility to change the inflation target of $2 \%$ upward or downward when it diagnoses that this is what is needed to ensure that the economy functions close to full employment with low risk of runaway inflation or deflation.

\section{BOX 1.1 DEFINITION OF UNEMPLOYMENT}

In market economies, some unemployment is considered necessary to prevent accelerating inflation. Therefore, the government's goal of elimination of unemployment is not equivalent to $100 \%$ employment - the employment of all the civilian labor force. The government counts as unemployed persons unemployed for 15 weeks or longer and people with temporary jobs who prefer permanent ones. Discouraged workers, those who were looking for a job for a long time but were unable to find employment, and, therefore, are inactive, are not considered officially unemployed.

Source: US Bureau of Labor Statistics. 
The $\mathrm{CB}$ uses the interest rate to guide the economy to a sustainable growth rate - stable inflation and low unemployment. ${ }^{3}$ Determining the sustainable growth rate and using the interest rate to ensure that the economy keeps growing at that rate is the art and science of central banking.

Figure 1.1 presents the economic functions of Kyber. We place Kyber on one of the corners of a triangle despite the fact that the other two corners are of no use - Kyber does not have to deal with the flows of private capital in and out of its borders and does not need to establish a price for its currency in terms of another currency. The shape of the triangle will be useful to us when we explain in Chapters 2-4 how the real multistate world copes with an intractable trilemma.

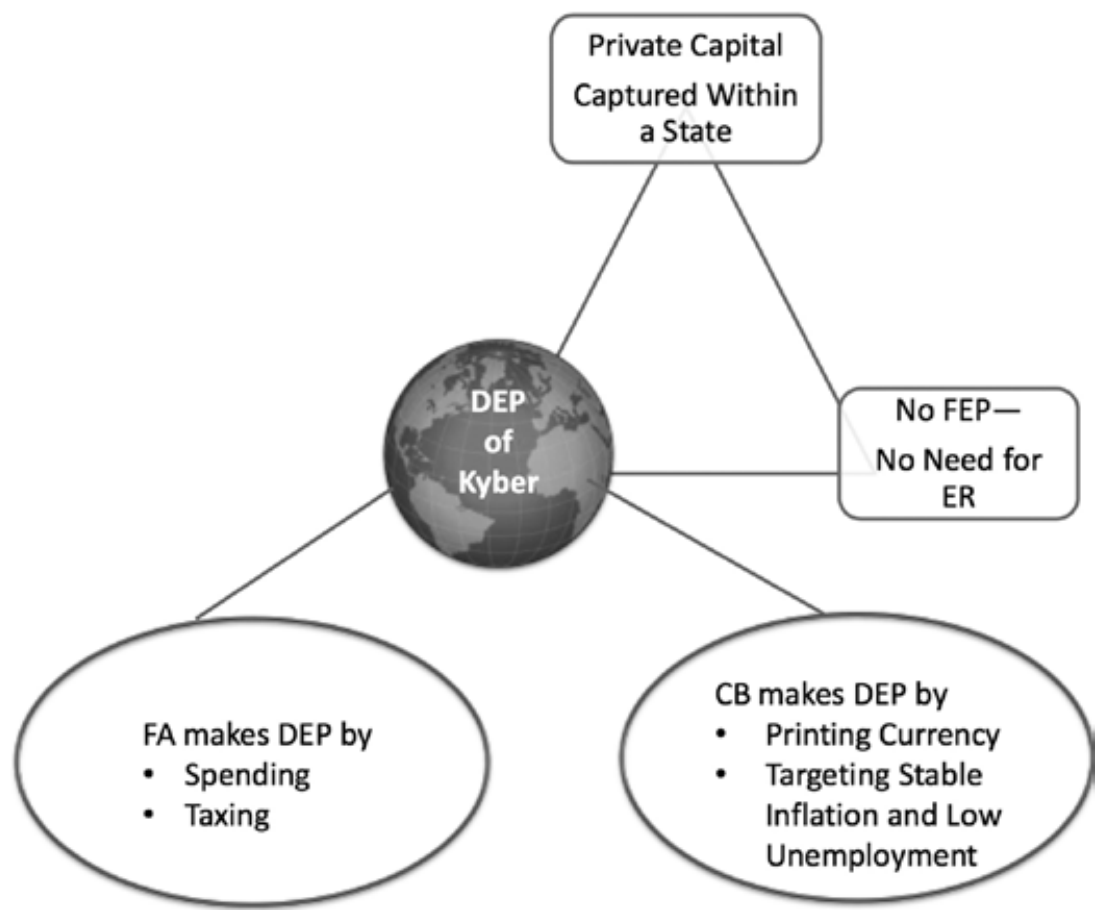

Figure 1.1 One-state economic policy

3 This is known as the Non-Accelerating Inflation Rate of Unemployment (NAIRU) - that is, low unemployment that does not produce more than the targeted inflation rate. 


\subsubsection{Calibrating the Economy: The Interest Rate}

A tool that the $\mathrm{CB}$ has at its disposal to guide the economy to sustainable growth (stable inflation rate with low unemployment) is the interest rate (IR) the cost of borrowing. The CB sets the benchmark IR in the economy, the rate that helps people decide how much interest to charge when they lend money to each other. If the economy is already growing at a sustainable rate, the CB will set an IR that is neutral - called also natural IR. This neutral IR keeps inflation stable, neither stimulating the economy nor slowing it down.

An inflation rate above $2 \%$ signals that the economy is overheating and the IR is below the natural rate. If the economy is overheating, inflation is above $2 \%$, the CB will increase its benchmark IR to encourage people to save. A high IR should boost savings and reduce borrowing. Since people would prefer to save rather than consume, this should reduce inflation (Fig. 1.2).

An inflation rate below $2 \%$ signals that the IR is above its natural rate and that it is choking off growth. In that case, the CB will decrease the benchmark IR to dampen savings and encourage borrowing. Citizens who spend rather than save can create revenues for businesses. These businesses, in turn, will invest more, generating economic growth (Fig. 1.2).

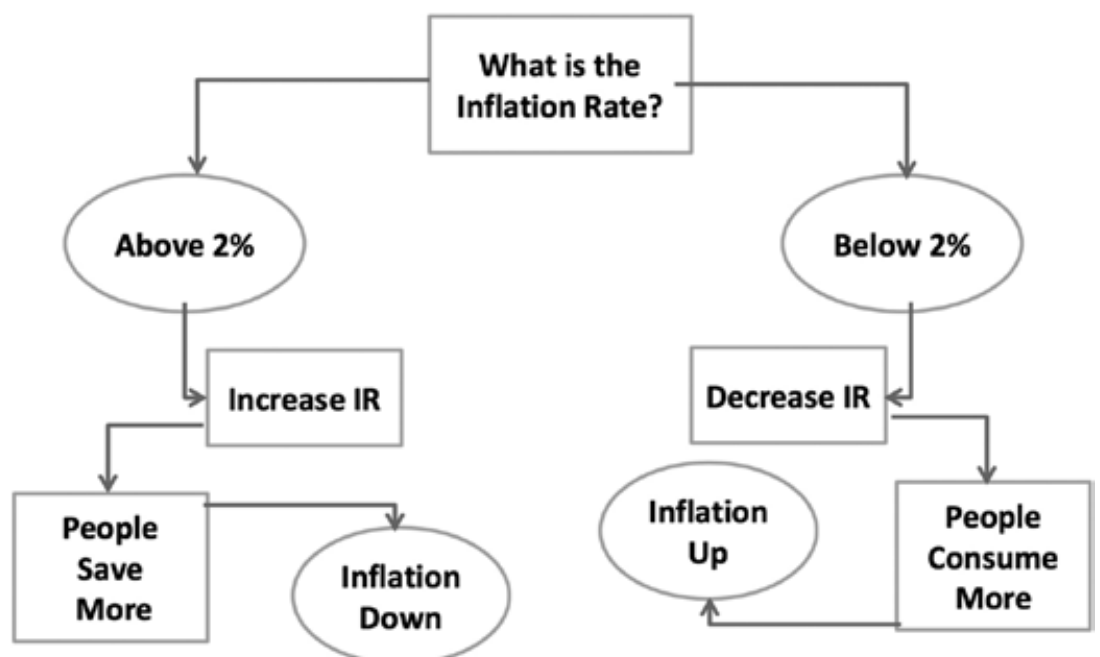

Figure 1.2 The IR as a tool of DEP 
In other words, the cues provided by the inflation rate help the CB infer the neutral IR. ${ }^{4}$ Sometimes, the $\mathrm{CB}$ will wait until there is clear evidence that the IR has diverged from the natural rate before changing it. Other times, it may decide to tweak the IR in a more preemptive way depending on the severity of risks that may threaten economic growth.

The CB sets the benchmark IR, but it does not dictate the market IRs. Borrowers and lenders bargain among themselves to set the IRs for individual loans. The various IRs set by this bargaining process take into account the benchmark IR set by the $\mathrm{CB}$ and add to it a risk premium that reflects the creditworthiness of various borrowers. People and business with bad credit, because they have defaulted on their loans in the past or have not paid back their lenders in time, tend to be charged higher IRs by the banks that lend money to them than people with good credit.

Furthermore, before making a decision whether to lend their money at all, creditors have to consider whether it is worth getting into the trouble of doing so. A high inflation rate can wipe out the returns that creditors receive when they lend their money. For example, if the benchmark IR set by the CB is $3 \%$, a commercial bank may decide to charge an $8 \%$ IR for a loan to a business adding a $5 \%$ risk premium to the benchmark $3 \%$ IR because of the bad credit of the borrower. If inflation runs at $8 \%$ per year, though, the bank may decide not to lend at all. This is because the interest it plans to collect from the borrower $(8 \%)$ will be wiped out by inflation ( $8 \%$ ). In other words, while the nominal IR is $8 \%$, and it seems high, the real IR is zero.

\subsubsection{The Banking System and Creation of Money}

Private banks are the intermediaries between the CB and the people. Individuals and businesses deposit their money with banks to safeguard it and earn an interest. Depositors are the banks' creditors. They deposit their money in checking accounts with banks and can demand, at any moment, their money back - including the interest accrued. The money people deposit with banks as on-demand deposits is called M1. People also deposit money in savings accounts. Setting money aside as savings in time deposits, ${ }^{5}$ that typically offer higher interest than regular deposits, helps people grow their nest egg for a rainy day. M2 is a measure of the money in the economy that includes these short-term time deposits that can be converted quickly into cash plus the

4 See Thomas Laubach and John C. Williams, Measuring the Natural Rate of Interest Redux, at 6, Federal Reserve Bank of San Francisco, Working Paper 2015-16, Oct. 2015.

5 A time deposit cannot be withdrawn before a specific date. 
M1. M1 and M2 measure how much money circulates in the economy that can be quickly converted into cash. The M1 and M2, unlike other assets like real estate, are the most liquid, cash-type, assets in the economy.

The role of banks is to recycle these liquid assets by lending them to firms and households. The traditional business of banking consists of borrowing money from depositors and lending it, at higher rates and over longer periods, to borrowers. Banks borrow short term from depositors and lend long term to various borrowers. Banks make money by offering depositors lower IRs on the money they deposit with them than those they charge borrowers. This is not usury. Banks need to be compensated for doing the work necessary to ensure that borrowers are creditworthy and will pay them back. In addition, banks take on the risk of maturity mismatch ${ }^{6}$ - they borrow short term but they usually lend long term to individuals, who may wish to buy a house, or to businesses that wish to invest in a new opportunity. This is a significant risk to undertake. During economic crises, depositors typically run to their banks en mass to collect their deposits and expect their money back on demand. However, the loans the banks have granted, by using these deposits, mature much later. Banks cannot ask borrowers to pay back loans that mature in years just because depositors are on their doorstep asking for their cash back.

Banking is a risky business and people are well aware of that. This is why they are unwilling to put their money in banks. To convince people that banks are safe, Kyber has introduced a deposit insurance scheme. Through this scheme it acts as the guarantor of the banking system. The government has figured out that $¥ 250000$ is the average amount that people keep in banks - the rest being invested in real estate and the stock and bond markets. It promises that, if banks fail, all people's deposits are guaranteed up to the amount of $\$ 250$ 000 per deposit account. Kyber is the only entity that can be trusted to keep this promise. Its $\mathrm{CB}$, that prints the currency, is capable of churning out as many kobanks as needed to ensure the government's promise is not an empty one.

Kyber has also adopted prudential regulation to prevent banks from loaning out all of the money deposited with them. Banks are required, by law, to keep with the CB or in their vault a percentage of the money deposited with them. This is the required reserved ratio (RRR). Banks are required to keep 10\% of the depositors' money as reserves - they can lend the remaining 90\%. Because banks are required to keep only a fraction of the money deposited with them as reserves, the banking system is called fractional reserve banking system (as opposed to the $100 \%$ reserve banking system, see Box 1.2). As demonstrated

6 Charles Engel, Macroprudential Policy in a World of High Capital Mobility: Policy Implications from an Academic Perspective, at 4, Working Paper 20951, Feb. 2015. 
in Figure 1.3, the fractional reserve banking system is the engine of money creation in the economy.

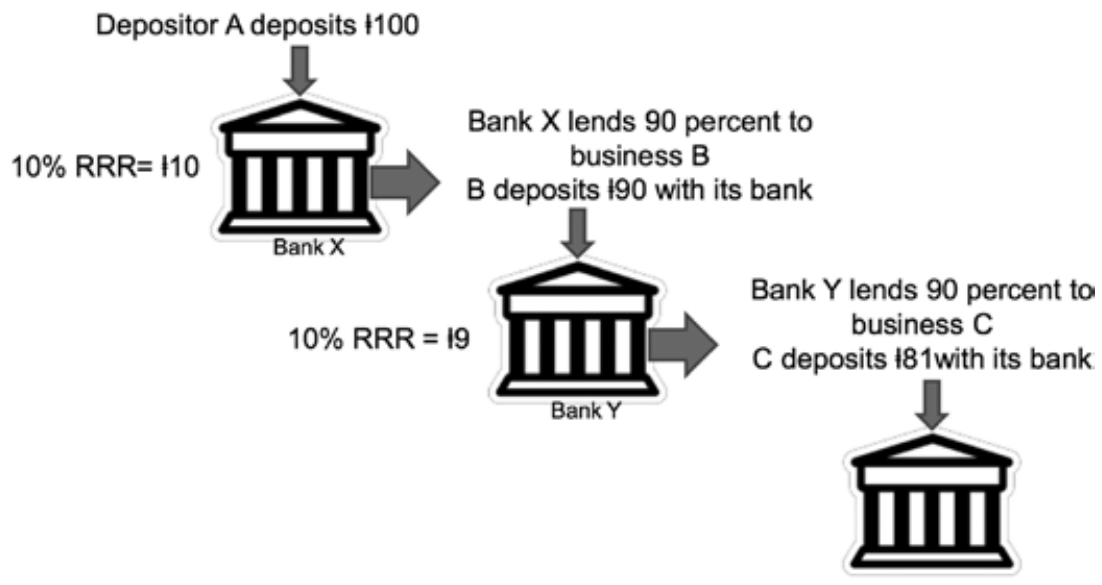

Out of the $\$ 100$ in initial deposits, banks are able to create $\$ 171(\$ 90+\$ 81)$.

Banks are required to keep only a fraction (10\%) of the money deposited with them and lend the rest. This is factional banking.

Figure 1.3 Money creation through fractional banking

\section{BOX 1.2 THE 100\% RESERVE BANKING SYSTEM}

The fractional reserve banking system adopted by Kyber is not the only possible banking system. The full (or 100\%) reserve banking system requires that banks keep the full amount of each depositor's money in cash, ready for immediate withdrawal on demand. Under this system, banks do not have the capacity to create new money in the form of credit as they currently do. Instead, the $\mathrm{CB}$ of a state is solely responsible for the creation of all money, including money in the form of credit. A full reserve banking system makes it possible for a state to have precise control over the money supply.

Source: Jaromir Benes and Michael Kumhof, The Chicago Plan Revisited, IMF Working Paper, WP/12/202, August 2012; Ronnie J. Phillips, The 'Chicago Plan' and the New Deal Banking Reform, Working Paper No. 76, Jerome Levy Economics Institute of Bard College, June 1992.

In addition to required reserves, banks may keep excess reserves. This happens when banks are unable (because there are not enough borrowers) 
Simplified balance sheet of a bank

\begin{tabular}{ll}
\hline Assets (what they own) & Liabilities (what they owe) \\
\hline Loans to firms and individuals & Deposits of clients \\
Reserves & Loans received from CB \\
Assets - liabilities = capital & \\
\hline
\end{tabular}

or choose not (because they fear borrowers may default) to lend some of the money deposited with them (Box 1.3).

\section{BOX 1.3 RESERVES OF PRIVATE BANKS}

Required Reserves* + Excess Reserves** $=$ Total Reserves***

$* 10 \%$ of deposits (by law), **optional, ***deposited with CB or in vault

The loans banks make ${ }^{7}$ and their reserves constitute their assets - what they own. Their depositors' money, ${ }^{8}$ and the money they borrow from the CB, are banks' liabilities - what they owe. The difference between assets and liabilities makes up banks' capital (Table 1.1).

Banks' liabilities can exceed their assets. This happens when individuals and businesses who borrow from banks cannot pay back their loans. If those who borrow from a bank cannot pay it back, the bank will be unable to pay back the money it owes depositors. Rumors of the imminent insolvency of a bank can generate a 'bank run'. Depositors run to the bank expected to become insolvent to collect the money they have deposited there. Bank runs often lead to bank failures. The bank, because it has used $90 \%$ of depositors' money to make loans, will not have the cash in hand to pay all depositors at once. Fears about the failure of a bank are highly contagious. Those who have deposited money with other banks may also panic and run on their banks. At this stage, the CB usually steps in to guarantee bank deposits, sometimes, even beyond the deposit guarantee limit of $\$ 250000$. The ability of the CB to act as the unconditional lender of last resort to the banking system restores confidence in it and averts further bank runs.

Some argue that the ability of a CB to act as the unconditional lender of last resort to the banking system creates moral hazard. Obviously banks have no incentive to refrain from aggressive lending - lending to people with bad

For a bank, the loans it makes are its assets; loans are liabilities to borrowers.

8 Your deposits with a bank are assets for you, but liabilities for the bank. 
credit at high IRs - if they believe that the CB will bail them out when their borrowers default. This puts the $\mathrm{CB}$ in a difficult position. If, during a panic, the $\mathrm{CB}$ does nothing and allows the banking system to fail, that failure will reverberate all through the economy. Since the banking system is the engine of money growth in the economy, the costs of closing down the banks will be borne by the society at large. The CB, in its role as lender of last resort, provides insurance to the banking system while being fully cognizant that this insurance breeds moral hazard. ${ }^{9}$ That is why it adopts measures, like the RRR, and enacts prudential regulations ${ }^{10}$ to control, as much as possible, the risk-taking of banks. Because of its pivotal role in maintaining the stability of the banking system, the $\mathrm{CB}$ has to decide when its lender of last resort function constitutes an efficient use of its deep pockets. ${ }^{11}$

\subsubsection{The Government Budget and Bond Market}

Kyber maintains an annual budget, which helps it keep track of how much it spends and how much it collects in taxes. If it spends more than it collects, it has a budget deficit. If it collects more taxes than what it spends, it has a budget surplus (Fig. 1.4). A government may have to run a deficit, for instance, if a disaster strikes and it has to provide disaster relief for the population. Governments can always deal with deficits by imposing more taxes. When a calamity hits, though, they often conclude that a disaster-hit citizenry would be unable to pay more taxes. A better option, then, is to borrow from the public instead of taxing it.

Kyber is willing to pay the public an annual IR on the amount of money it borrows from it. To facilitate borrowing, it has developed a market that makes it possible for people to buy government debt in the form of 'bonds'. Bonds are IOU certificates that denote the amount of money borrowed by the government, and for how long, and the rate of interest, the coupon rate, the government pays to those who hold its debt. When the bonds mature, it is time for the government to pay back the money it borrowed. Figure 1.5 is a depiction of a bond certificate. The holder of the certificate has lent the government 11000 , denoted as the bond's face value, for which she would receive a yearly interest of $5 \%(150)$. When the bond matures on June 1, 2050, the holder of the certificate will get back her principal, the 11000 she lent to the government. The FA sells bonds to banks and individuals through public auctions. The auctions take

\footnotetext{
9 Engel, supra note 6, at 22.

10 See Chapter 16.

11 Tamim Bayoumi et al., Monetary Policy in the New Normal, at 20, IMF Staff Discussion Note SDN/14/3, Apr. 2014.
} 


\section{Types of Government Budget}

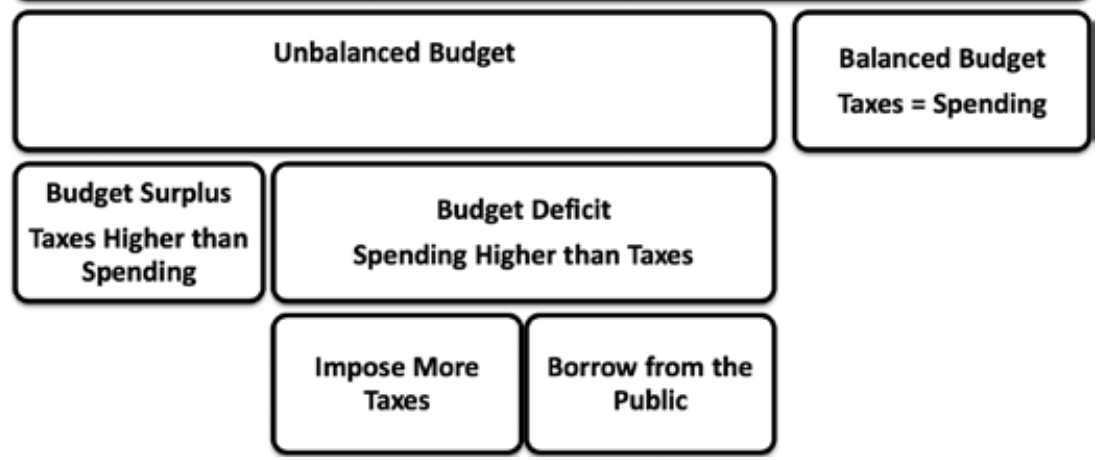

Figure 1.4 Government budget

place regularly. There are three steps to an auction: the announcement of the auction, the bidding for the bonds by individuals and banks, and the issuance of purchased bonds.

\section{$\$ 1000$ Face Value \\ Kyber \\ General Obligation Bond \\ $5 \%$ coupon rate}

Payable Annually

On June 1

Matures on June 1, 2050

Figure $1.5 \quad$ A bond certificate 
The FA has designated certain banks to be the primary dealers ${ }^{12}$ in the government bond market. An FA-designated primary dealer is a market maker. The dealer buys government bonds directly from the government, with the intention of reselling them to others, thus making a market for government bonds. The primary dealers, the market makers, are required to bid on a pro-rata basis in all FA auctions at reasonably competitive prices. After buying the bonds from the government, those who hold them can sell them in the open market, also called the secondary market. This secondary market for government bonds is a 'deep and liquid' market, which means that people active in that market can rapidly buy and sell a large amount of bonds with little impact on their prices. ${ }^{13}$ In the open market, bonds may be sold above or below their face value. When bonds sell above their face value they sell 'at a premium'. When they sell below their face value they sell 'at a discount'. Bonds may sell at a premium or discount because of changes in the IRs. From the time of purchase, until the time buyers decide to sell their bonds, the prevailing IRs in the economy may have changed. In fact, in dynamic market economies, IRs rarely remain the same. They change based on changes in the benchmark IR set by the CB and the supply/demand dynamics in the bond market.

As mentioned above, a 11000 face value bond that has a coupon rate of $5 \%$ will pay 150 to the bondholder every year (Fig. 1.5). If the market IR is 7\%, and a bondholder wants to sell the bond, she will receive less than the amount she paid for it. When the prevailing IR in the economy is higher than the coupon rate, the bond's price has to drop so that investors can be enticed to buy the bond. Obviously, people will refuse to purchase a bond that offers a 5\% return when they could invest their money in another asset and get the higher market rate of $7 \%$. The lack of demand for the bond pushes its price down and the bond will sell at a discount. Conversely, a bond that offers a coupon rate that is higher than the prevailing market IR will sell at a premium. People should rush to buy bonds that offer higher coupon rates than the market IRs. As a result, the price of those bonds will increase and they will sell at a premium. In the open market, there is an inverse relationship between the market IRs and bond prices. When the IRs are up, bond prices are down. When the IRs are down, bond prices are up.

Overall, the factors that affect the prices of bonds in the open market have to do with the supply and demand for bonds and IRs associated with their maturity (Box 1.4).

12 In the United States primary dealers are big private banks, such as Barclays, Citigroup, Credit Suisse, Deutsche Bank, Goldman Sachs and HSBC.

13 BIS Committee on the Global Financial System, How Should we Design Deep and Liquid Markets? The Case of Government Securities, at 1, n. 1, Oct. 22, 1999. 


\section{BOX 1.4 FACTORS AFFECTING BOND PRICES}

- Supply/demand for bonds

- Market IRs (when IRs down, bond prices up and vice versa)

- Their maturity

\subsubsection{Government Debt as a Public Good}

The bond yield, the return that investors expect to receive by holding a bond, has to do with the market IR associated with the maturity of that bond (Box 1.4). The yield curve shows how much money we can make by buying government debt. It is the chart of expected yields - the returns that investors hope to receive by holding bonds of different maturities. Figure 1.6 plots the yields of bonds that mature in 5, 10, 15, 20, 25 and 30 years. The yield curve is typically normal, upward slopping, because the longer one is willing to hold a bond, the higher the risk she takes on. She expects, therefore, a higher return on her investment. This makes sense because the further one looks into the future, the higher is the uncertainty that unanticipated events may derail the economy. Investors should be compensated for the risk they undertake by holding longer-term bonds. A flat yield curve is abnormal because it indicates that those who invest in long-term bonds will receive the same returns as those who invest in short-term bonds. Therefore, they will not be rewarded for extra risk they take on by investing in long-term debt. A flat yield curve indicates uncertainty, that something may be wrong with the economy, maybe an upcoming recession. An inverted yield curve is the most abnormal since it signals that short-term debt is expected to pay more than long-term debt. The anticipation that the IRs may fall in the future, owing to a potential economic contraction, causes the yield curve to invert. Financial forecasters are wary of inverted yield curves. Strongly inverted yield curves have been correlated with recessions.

The slope of the yield curve for government bonds is an indicator of a state's expected future economic performance. A normal yield curve indicates inflationary growth. A rising inflation dents the regular income that bondholders receive by purchasing bonds. When inflation is up the yield curve is normal because bondholders know that the longer they hold a bond the higher the chance is that their returns will be eaten up by increasing inflation. Therefore, the government has to offer them higher IRs to entice them to buy long-term, instead of short-term, bonds. Recessionary conditions, on the other hand, make bonds appealing because they offer a steady source income even in economic downturns. During recessions, people will not mind investing in long-term 

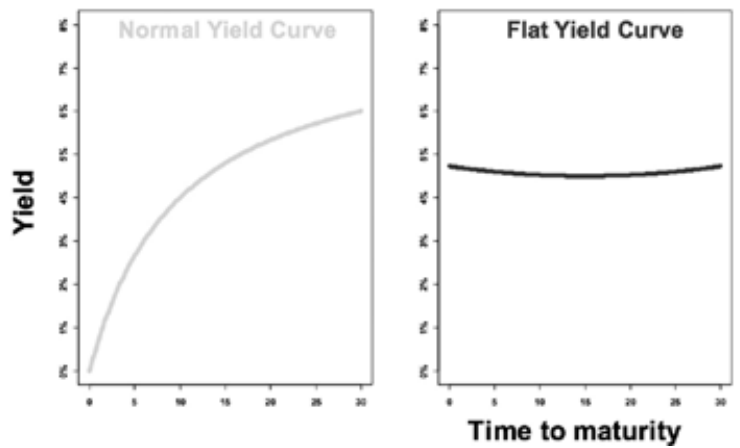

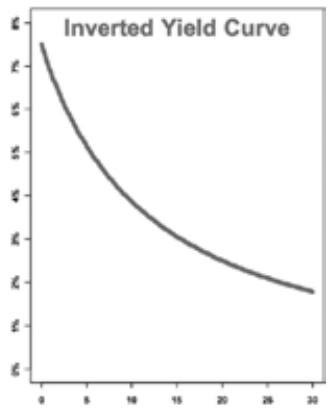

Figure $1.6 \quad$ The yield curve

bonds even if those bonds offer lower yields than short-term bonds. This is especially so if they expect that bonds that will be issued in the future will offer even more meager returns. During recessions, therefore, the yield curve could be flat or inverted.

Besides the yield curve that depicts the expected returns on government bonds, other yield curves can be put together to help investors gauge the expected returns on corporate debt. Since corporations, whose profits fluctuate from year to year, are considered less creditworthy than the state, the yields offered by the bonds they issue are typically higher than those offered by government bonds. Companies pay a risk premium on the debt they issue to entice the public to invest in their debt rather than the safer government debt. Because Kyber has the ability to print its currency and to tax future generations to pay back its debt, government debt is the safest asset. In fact, holding short-term government bonds is considered as safe as cash. During an economic recession, people prefer to invest in government debt and will shun other more risky investments, such as corporate bonds or stocks. Because the state's debt is considered safe, it is also the most preferred kind of collateral in the economy. Collateral is a borrower's pledge of a specific asset (such as property, gold jewelry, stocks or government bonds) to a lender to ensure the lender that she will pay him back. ${ }^{14}$ The fact that lenders prefer to hold as collateral government bonds, pieces of paper that certify that the government owes them money, instead of precious metals such as gold, tells us a lot about

14 The provision of collateral, in other words, protects a lender from a borrower's default. If a borrower fails to pay the principal and interest under the terms of the loan (i.e. defaults) it has to forfeit the asset she pledged as collateral. The lender becomes the owner of that asset. 
the stature of the one and only state and the care it has put into developing the government debt market.

Kyber, in fact, views the establishment of the yield curve for the debt it issues as a financial infrastructure project - a fundamental building block of its economy. Since Kyber's debt is the safest asset, it is used to make economic policy and price all other debt in the economy. To calculate the IR for other borrowers, like businesses and households, one must take into account the government's risk-free rate and add to it a risk premium. The higher the risk of default of a borrower, the higher the risk premium she will have to pay.

The FA plays a central role in establishing and maintaining the yield curve. One of the tasks of the FA is to put together a deep and liquid government debt market by making available enough debt at various maturities to support active trading. Without active trading, bond prices may become volatile and unpredictable, and an unpredictable government debt market will generate uncertainty in other credit markets. As we explained before, the IRs for private lending are based on the risk-free rate enjoyed by the sovereign. Banks add a premium to the risk-free rate depending on the creditworthiness of each borrower. Therefore, if the rate enjoyed by the state fluctuates dramatically from day to day, this could cause high volatility and thus instability in the private lending markets.

In Chapters 3 and 4, we will demonstrate how, in the real world, the debt of certain states functions as a global safe asset, an asset everybody covets to acquire as a stable source of income. States, in fact, take pride when other states and private actors invest in their debt because they think of it as risk-free investment.

\subsubsection{Tools of Economic Policy}

The FA controls money by taxing, spending and borrowing from the public. The CB controls money by establishing the benchmark IR for the whole economy. Another tool of the $\mathrm{CB}$, as we will see below, is the buying and selling of government debt, issued by the FA, in the open market. In fact, the coordination, between the FA and $\mathrm{CB}$, on how to manage government debt is essential for the smooth functioning of the economy. Economic policies can be contractionary (tight), expansionary (lose) or neutral. Contractionary policies are implemented when the economy is growing at an unsustainable rate, creating risks of high inflation. Expansionary policies are used to treat economic downturns and alleviate recessions. Neutral polices are endorsed when the economy is growing at a sustainable rate but the $\mathrm{CB}$ is watchful for signs of accelerating inflation or deflation. Economic policies can never be completely neutral, though. This is because their target is an inflation rate of $2 \%$. There 
is an inflation bias in economic policy because low to moderate inflation is considered supportive of growth.

The FA and CB control the money in the economy by manipulating the monetary base (MB) called also high-powered money. The $\mathrm{MB}$ is the sum of currency in circulation (C) and the total reserves (R) of banks, the official liquidity available in the financial system $(\mathrm{MB}=\mathrm{C}+\mathrm{R}$; Box 1.5). Currency in circulation - the hand-to-hand money held by the public ${ }^{15}-$ is currency not deposited with banks. The total reserves of banks are the money they deposit with the $\mathrm{CB}$ or money they hold as physical currency in their vaults (Box 1.3).

\section{BOX 1.5 MONETARY BASE (MB) OR OFFICIAL LIQUIDITY}

$$
\text { Total Reserves of Banks (R) + Money in Circulation (C) }=\text { MB }
$$

The MB is the official liquidity, how much money the public sector makes available in the economy. As seen above (Fig. 1.4), banks can also create private money by using the official MB to provide credit to individuals and firms. The money that banks create though the fractional reserve banking system is the money supply (MS) or private liquidity (Box 1.6). The government, the FA and CB can affect the MB - the official liquidity. However, they cannot directly affect the MS - the readiness of banks to lend (and people to borrow) - the private liquidity. In a market economy, it is willingness of people to borrow and banks to lend that transmits the official economic policies to the real economy.

\section{BOX 1.6 MONEY SUPPLY (MS) OR PRIVATE LIQUIDITY}

$$
\begin{gathered}
\text { MB } \times \text { Transmission Mechanism* = MS } \\
\text { *Willingness to Borrow \& Readiness to Lend }
\end{gathered}
$$

\subsubsection{Tools of fiscal authority}

The FA controls the MB by taxing and spending (Box 1.7), but it does not have direct control over the MS. When the FA wishes to battle a runaway inflation, it must increase taxes or decrease spending. The more the FA taxes people, the

15 Milton Friedman and Anna Jacobson Schwartz, A Monetary History of the United States 1867-1960, at 50 (1963). 
less the MB, the official liquidity in the economy, is. People whose income is decreasing owing to taxation should consume less and save more and their parsimony should shrink the incomes of producers who will produce less and contract the economy. A tight fiscal policy should force prices down and tame inflation, but at the risk of slower growth and higher unemployment.

\section{BOX 1.7 TOOLS OF FISCAL AUTHORITY}

$$
\text { Tax }- \text { Borrow }- \text { Spend/Invest }
$$

Contractionary policies can have unintended consequences, though. Some people may conclude that tax hikes are now a permanent feature of government policy. Therefore, they may decide to start saving an increasing percentage of their income to pay for future taxes. These savings should boost banks' reserves. Banks should, in turn, lend these excess reserves to increase their profits. In fact, their abundant reserves may tempt banks to espouse aggressive lending tactics, to invent schemes to lure less creditworthy individuals into borrowing. All in all, the ample availability of credit, owing to the rise in savings, may trigger an economic expansion rather than the contraction that the FA was aiming for.

The pursuit of an expansionary fiscal policy to battle deflation and a debilitating recession can also have side effects. Obviously, the less the FA taxes or the more it spends, the more the MB, the official liquidity in the economy, is. People whose income is growing because they pay fewer taxes may decide to consume more. This should boost business profits, lower unemployment and expand the economy. However, the FA may overshoot its goal and cut taxes too much. This could produce an exuberant consumption that accelerates inflation and erodes the savings base in the economy. At the other extreme, not all people whose income has increased owing to tax cuts would be eager to consume that extra income. They may decide, instead, to save it because they know that expansionary policies tend to be transitory. If the majority of people share this mindset, the FA's expansionary policy will probably fail.

Finally, the FA can affect the MB by borrowing (Box 1.7). Since short-term government debt is considered equivalent to cash, issuing short-term bonds is like printing currency. The FA can take advantage of the like-money properties of the short-term debt it issues. If it decides, for instance, to substitute some of its long-term debt with short-term debt, the MB should increase. If, on the other hand, it replaces some of its short-term debt with long-term debt, the MB must decrease. It is not guaranteed, however, that changes made in the composition of government debt will eventually cascade down to the economy and alter the behavior of the public. 
Overall, it is hard to accurately predict the impact of fiscal policy on the economy. Fiscal measures are, therefore, considered imprecise tools of economic policy. The FA can change the MB but how this will affect the MS depends on how people and business react to a fiscally engineered expansion or contraction. An expansionary fiscal policy may boost inflation more than intended while a contractionary policy can really depress growth and dampen employment.

\subsubsection{Tools of central banks}

Monetary policies tend to have a more direct impact on the economy than fiscal policies. Central banks control the benchmark IR that they can increase to cool down the economy or decrease to spur growth. However, figuring out the IR that suits an economy is not easy. During an inflationary period, for instance, a small increase in the benchmark IR may not be sufficient to beat inflation. A drastic increase, on the other hand, may knock down inflation but also depress economic growth. Determining the exact IR that would produce desirable economic outcomes has to do with the skills, experience and luck of central bankers.

\section{The interest rate}

The CB, like the FA, can adopt expansionary or contractionary policies depending on the needs of the economy. The benchmark IR set by the CB (Box 1.8) affects, in normal circumstances, all of the IRs in the economy. If the economy is in recession, the $\mathrm{CB}$ can cut down the benchmark IR to encourage spending and investment. Decreasing the IR makes saving less enticing and spurs investment and consumption. The $\mathrm{CB}$ has to decide by how much to decrease the IR and for how long to achieve its goals. There is a danger that the CB may keep the IR too low for too long. In that case, the increase in consumption and borrowing may fuel inflation and unsustainable high prices, 'bubbles', in the housing and stock markets - 'asset bubbles'.

\section{BOX 1.8 TOOLS OF CENTRAL BANK}

- Benchmark IR $\rightarrow$ Up/Contractionary, Down/Expansionary

- Government Bonds $\rightarrow$ Buy/Expansionary, Sell/Contractionary

- $\quad \mathbf{R R R} \rightarrow \mathrm{Up} /$ Contractionary, Down/Expansionary

- Loans to Banks $\rightarrow$ More/Expansionary, Less/Contractionary

When the economy is overheating, the inflation rate is above target, and the CB should increase the benchmark IR (Fig. 1.2). High IRs should entice people to save instead of borrowing. However, again the $\mathrm{CB}$ must decide by 
how much to increase the IR and for how long. A drastic increase in the IR may remedy high inflation but can also sink the economy into recession.

In normal circumstances, an IR hike should make people less willing to borrow and an IR cut should make them eager to spend and invest. These are not guaranteed outcomes, however. In a deflationary economy, even near-zero IRs may not be enough to entice people to consume and business to invest. This is especially so if people have been traumatized ${ }^{16}$ by a prolonged recession and are pessimistic about the future. As a result, they are reluctant to borrow no matter how much the IRs decline. In an inflationary economy, in a similar fashion, people may be indifferent to IR hikes because they are irrationally exuberant ${ }^{17}$ - they believe in never-ending growth. They do not hesitate to borrow no matter how much the CB keeps ramping up the IRs.

In summary, the $\mathrm{CB}$ can tweak the IR to accelerate or decelerate the economy, but how that tweaking will exactly affect the economy cannot be pre-determined.

\section{Changing the RRR}

The CB can change the MB by manipulating the RRR (Box 1.8). Manipulating the RRR targets the behavior of lenders, the banks. During a recession, for instance, banks tend to keep too much liquidity trapped in excess reserves (Box 1.3) because they fear that potential borrowers may become insolvent. If banks keep reserves above the RRR, instead of lending them, the CB can cut down the RRR. Reducing the RRR from 10 to 5\%, for example, may convince banks to unload some of their excess reserves because, given the new RRR, they are now awash with cash. Conversely, the CB can increase the RRR when banks engage in risky lending behavior. An RRR hike will force banks to set more deposits aside as reserves and this should curb their appetite to lend.

Kyber's CB prefers not to make abrupt changes in the RRR though. Increasing the RRR may shock some banks, which will scramble for extra cash, and can cause an undesirable economic contraction. Decreasing the RRR may also give the wrong signal and unleash excessive lending. How exactly banks will behave when confronted with a changed RRR has to do with their outlook on the economy. The $\mathrm{CB}$ can manipulate the RRR to nudge banks to

\footnotetext{
16 Alan S. Blinder, The Economy has Hit Bottom, WSJ, July 23, 2009 (referring to 'traumatized consumers who have suddenly learned the virtues of thrift').

17 'Irrational exuberance' was a phrase used by the US Federal Reserve Board Chairman Alan Greenspan before the bursting of the dot-com bubble. See Alan Greenspan, The Challenge of Central Banking in a Democratic Society, Remarks at the Annual Dinner and Francis Boyer Lecture of the American Enterprise Institute for Public Policy Research, Dec. 5, 1996.
} 
behave a certain way. However, in a market economy, it cannot command banks to slow down or accelerate lending.

\section{Loans to banks}

A CB can stimulate a sluggish economy by offering loans to banks (Box 1.8). A CB usually stands ready to lend to private banks because it expects that they will use these loans to expand their lending to businesses and individuals. Still, banks are the ones that make the decision whether to borrow from the CB. In principle, the lower the lending rate, the more willing a bank should be to borrow from the $\mathrm{CB}$. The discount rate offered by the $\mathrm{CB}$ to entice banks to borrow from it may not be enough, though, if banks are not optimistic about the economy. If banks expect a large number of defaults on the loans they make, they may be reluctant to borrow from the CB even at a discount rate.

All in all, though, the discount rate is a potent monetary tool. During financial crises depositors typically withdraw their deposits and banks refuse to lend to each other. Loans granted by the CB can help many private banks weather tough economic times.

\section{Buying and selling government bonds}

Open market operations are another tool of monetary policy (Box 1.8, Fig. 1.8). Open market operations consist of the buying and selling of government bonds in the open (secondary) market. We must note here that a government entity, the CB, can buy, hold or sell the debt issued by another government entity, the FA. The CB cannot purchase these bonds directly from the FA though. Such direct buying of government debt from the FA would make it obvious that the government can be financed by its own CB. Yet, while the CB cannot buy government debt directly from the FA, it can buy such debt in the secondary market by placing an order with the primary dealers (Fig. 1.7).

The buying/selling of government bonds by the $\mathrm{CB}$ has a direct effect on the MB. For example, when the CB buys 110000 worth of government bonds, it writes a check to the bank, the primary dealer, from which it purchases the bonds. The bank can keep the check in its checking account at the CB or cash it and put the money in its vault. In both cases, the reserves of the bank have increased, which means that the MB has increased by $\$ 10000$ (Box 1.5). The bank can use these reserves to make loans to businesses.

If banks use the money that the $\mathrm{CB}$ creates, by buying government bonds from them, to make loans to businesses and individuals, the CB's expansionary policy will stimulate the economy. However, if banks hold on to the injected cash and do not lend it further, the expansionary policy will probably fail (Fig. 1.8). The $\mathrm{CB}$ controls the $\mathrm{MB}$, the official liquidity it makes available to the banking system. It has less control over the MS (Box 1.6) because banks decide whether to keep as reserves or lend the money the CB creates. When 


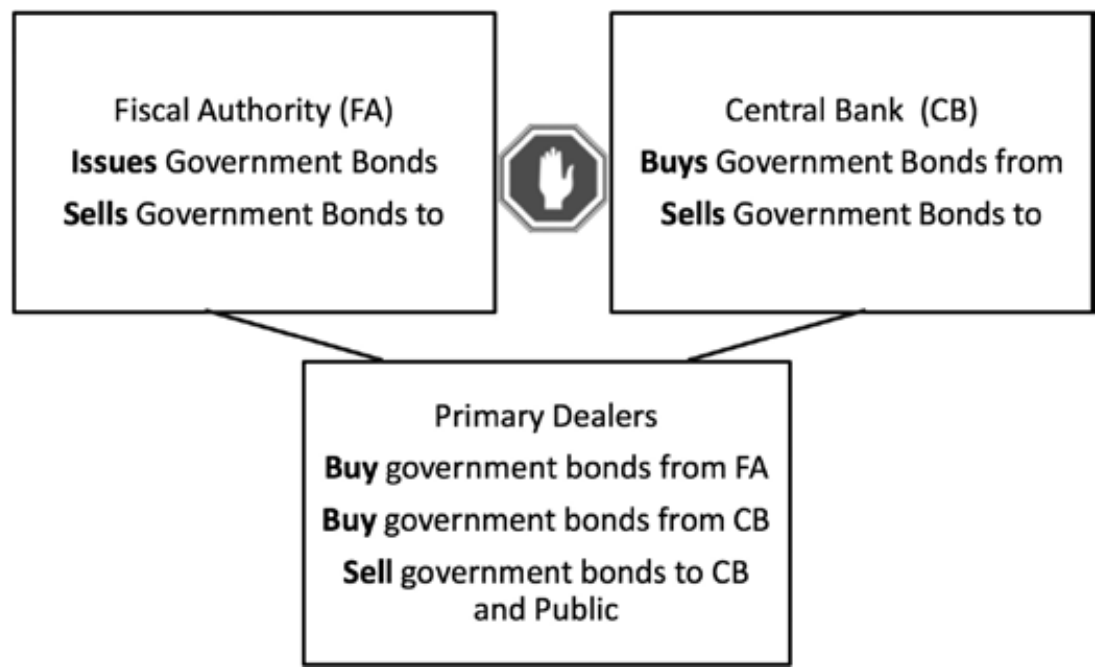

Figure 1.7 Management of government debt. The role of $F A$ and $C B$

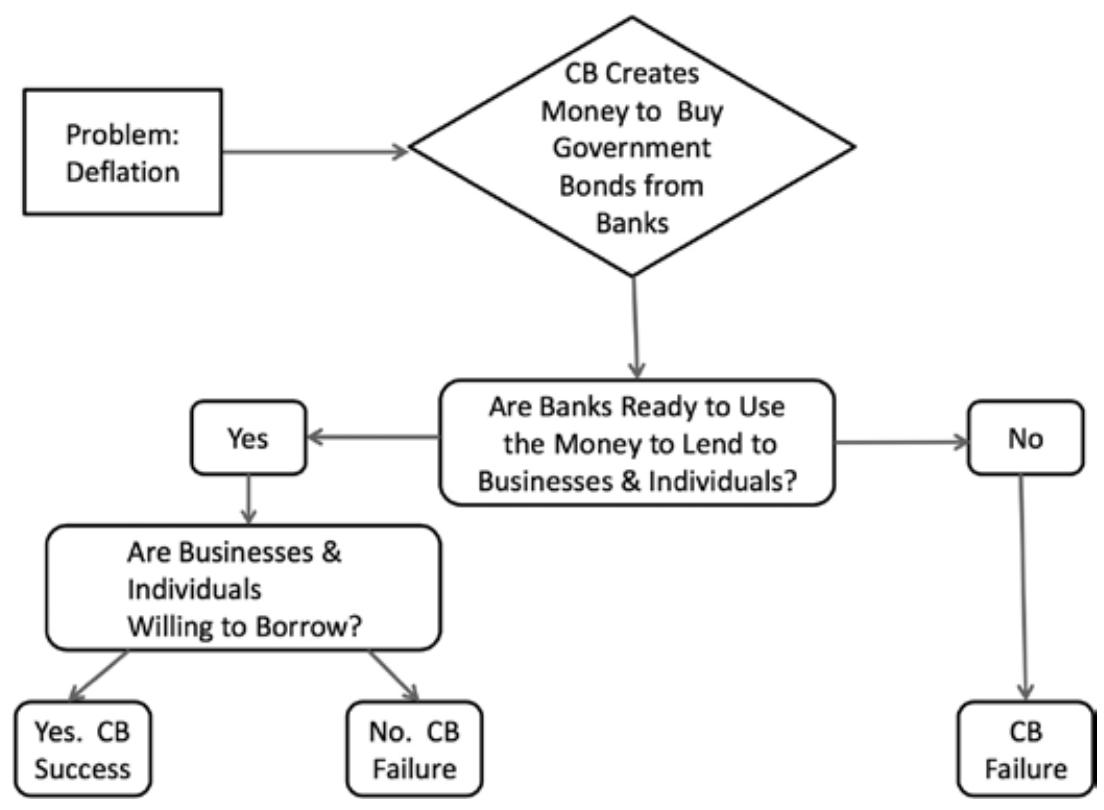

Figure $1.8 \quad C B$ 's open market operations

an economy is suffering from a recession, banks are typically reluctant to lend because of fears that borrowers might default. Potential borrowers are also 
unwilling to borrow and often withdraw money from banks. The CB is well aware that when the economy is deep into a recession the transmission mechanism (Box 1.6) from the MB to the MS will probably operate in an inefficient way.

In comparison with other monetary tools, the buying and selling of government bonds is the most precise one. Open market operations work directly on the MB by injecting or withdrawing liquidity from the economy. They are flexible and easily reversible since open market purchases can be reversed with open market sales and vice versa. Because buying and selling government debt is a convenient tool of monetary policy, if Kyber decides to run a conservative fiscal policy, balancing its budget and getting rid of debt, it can create a problem for its $\mathrm{CB}$. When government debt becomes scarce, the $\mathrm{CB}$ will have to figure out some other securities to buy and sell to make monetary policy. ${ }^{18}$ Unfortunately, there are no securities that are as safe as government bonds. ${ }^{19}$

In conclusion, the FA, by issuing bonds, the $\mathrm{CB}$, by its bond buying or selling, and private actors, who may seek these bonds as a way to invest in safe assets, are the major players in the bond market (Box 1.9).

\section{BOX 1.9 FACTORS AFFECTING THE PRICE OF GOVERNMENT BONDS}

- Their Maturity

- Supply of bonds by FA

- Demand of bonds by $\mathrm{CB}$ and public

- Market IRs

\subsubsection{Fiscal authority and central bank coordination}

The FA and the CB have many tools at their disposal to control the economy. The FA taxes, spends and borrows (Fig. 1.9). The CB sets the benchmark IR, calibrates the RRR and the discount rate, the rate at which it lends to private banks (Fig. 1.9). Both the FA and the CB manage the government debt as the

18 This was an issue faced by the European Central Bank (ECB) in 2017 when the largest and economically most powerful country in Europe, Germany, balanced its budget, creating scarcity for its debt that was considered the most risk-free asset in Europe.

19 Maurice Obstfeld, International Monetary System: Living with Asymmetry 301, at 308-9, n. 8, in 'Globalization in an Age of Crisis: Multilateral Economic Cooperation in the Twenty-First Century' (Robert C. Feenstra and Alan M. Taylor, eds, 2014). 
FA borrows money from the public, by issuing government bonds, and the CB may decide to buy or sell government debt, as it sees fit, to calibrate the economy (Fig. 1.9). As mentioned above, the CB can buy government debt, through the primary dealers, in the open market by creating money (Fig. 1.8). When the CB buys government debt, it monetizes it - it transforms it into money.

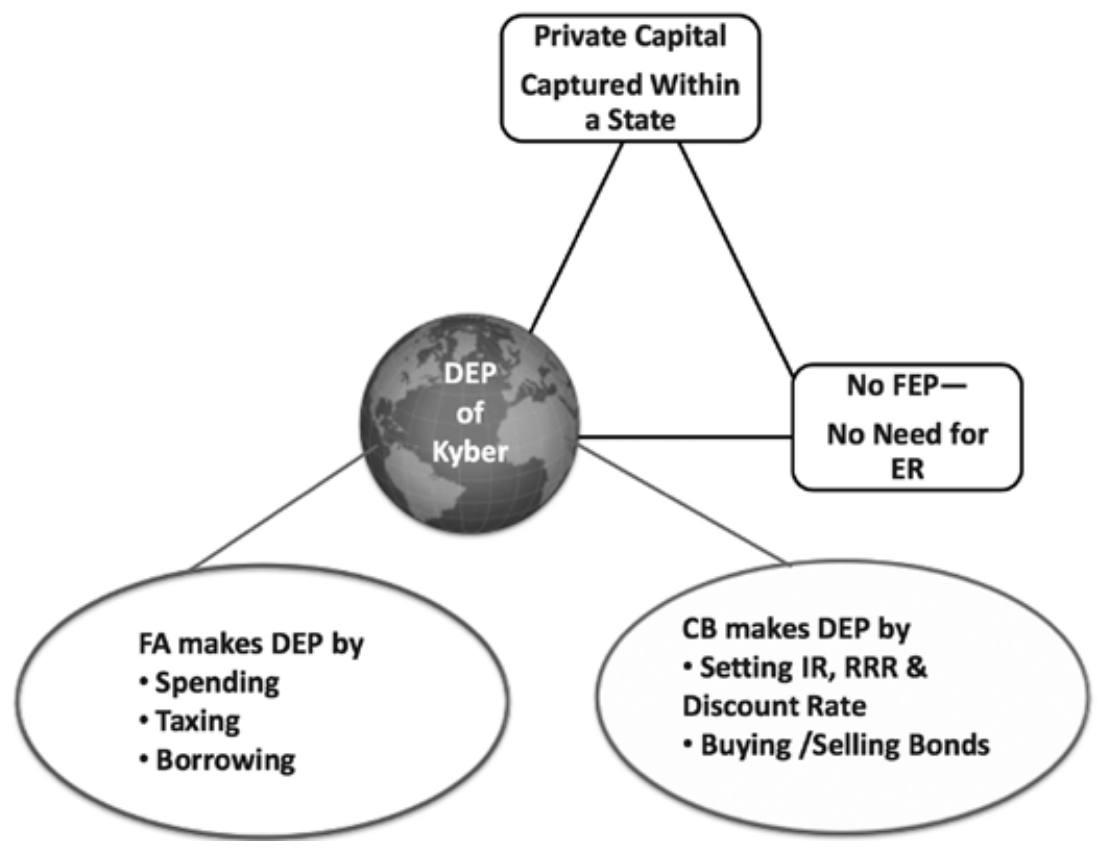

Figure $1.9 \quad$ Tools of economic policy

The debt issued by the FA and bought by the $\mathrm{CB}$ is a liability for the FA but an asset for the CB. A consolidated balance sheet of the FA and CB would cancel this debt out (Fig. 1.10).

The question here is why would any state decide to manage its economic affairs through two entities - the FA and the $\mathrm{CB}$ - and then engage in the shenanigans of having its own CB create money to buy the debt issued by the FA? The answer is self-discipline. The state controls the printing press that enables it to create as much money as it wishes. However, having the power to print money is not always a blessing. The government knows that citizens are aware that the currency it prints, and passes on to them as a medium of exchange and store of value, is in essence plain paper with the state's insignia on it. If a natural disaster, an internal insurgency, a terrorist act were to destroy 


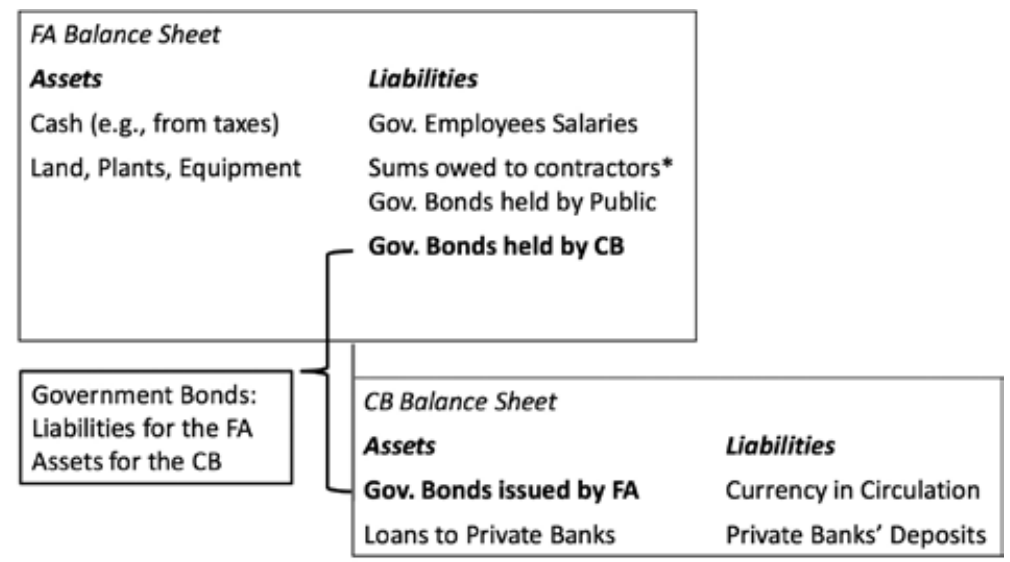

*companies that build highways, bridges etc.

Figure 1.10 Simplified balance sheets of FA and $C B$

the state, its paper currency would probably collapse with it. Kyber, in our example, is aware that the value of its currency depends on the faith people have in it. While currency can be printed in abundance, there is a limited amount of resources and, therefore, a limited amount of goods and services that can be made with these resources. Too much money chasing finite resources, goods and services can trigger uncontrollable inflation and deplete the currency's value.

The separation of powers between the FA and the $\mathrm{CB}$ is central for the long-term survival of the state. The FA spends on infrastructure, transportation, education, bread and circuses to keep the population happy. Some of these expenses are crucial for reducing internal opposition, terrorist activities and crime. The $\mathrm{CB}$ operates the government's printing press and can print currency incessantly to pay for all of the FA's expenses. Such incontinent money printing, though, will cause hyperinflation, the debasement of currency and possibly the dethroning of Kyber's government. Separating the FA from the $\mathrm{CB}$ is the institutional control that helps ensure the state's longevity. The state tries to preserve itself by assigning economic policy to two branches: the FA that is responsible for spending and the CB that prints the currency. The government has adopted legislation that plainly states that the $\mathrm{CB}$ is independent from the FA. The FA, in other words, cannot order the CB to print money to cover government expenses. The FA cannot even borrow directly from the 
$\mathrm{CB}$. The overt monetary financing of the government by its $\mathrm{CB}$ - the so-called 'helicopter money' ${ }^{20}$ - because it is as close as we can get to creating money from scratch like when a helicopter drops money from the sky - is prohibited. However, while overt monetary financing is proscribed, covert monetary financing is still possible since the $\mathrm{CB}$ can buy government debt in the open market from the primary dealers. The primary dealers, by playing the role of intermediary between the FA and the $\mathrm{CB}$, interject a degree of separation between the two branches of the same government (Fig. 1.7).

Obviously Kyber can get rid of its independent CB and command it to obey the FA. In fact, in emergency circumstances, it might just decide to do so by ordering the $\mathrm{CB}$ to buy government debt directly from the FA. In regular circumstances, though, the FA and CB prefer to collaborate at arm's length. The FA cannot order the $\mathrm{CB}$ to buy government debt to finance budget deficits. The $\mathrm{CB}$ does not have to monetize government debt if it believes that this is bad for the economy. There are limits to that independence, though. ${ }^{21}$ The $\mathrm{CB}$ cannot be completely independent from the government because it is part of it.

\subsection{A FRAMEWORK FOR ECONOMIC POLICY: THE FOUR SCENARIOS}

In this section, we assume that a government's CB and FA coordinate to ensure that the economy grows at a sustainable growth rate. However, the FA tends to have the upper hand in this relationship - what is called fiscal dominance. This is because it makes the key economic decisions: how much to tax people and business and how much to spend and borrow. As we saw above, the government, through its fiscal branch, has the capacity to order the CB to print all of the money it needs for its spending. It refrains from doing so, though, because of fears that inflation will destroy the value of the paper currency it prints. The government has established the $\mathrm{CB}$ as an independent institution made up of experts whose job is to calibrate the money available in the economy to promote sustainable growth.

Figure 1.11 depicts the policy options of a CB by taking as a given the state of the economy and fiscal policy. The horizontal axis provides a snapshot of

20 Milton Friedman, The Optimum Quantity of Money 4-8 (2005 edition); Jordi Galí, The Effects of a Money-financed Fiscal Stimulus, at 2, Working Paper, Centre de Recerca en Economia Internacional (CREI), Aug. 2017; Adair Turner, Debt, Money, and Mephistopheles: How Do We Get Out of This Mess?, at 2, Occasional Paper 87, Group of 30, 2013.

21 On the limits of CB independence, see Rosa Lastra, International Financial and Monetary Law 2.104-2.158 (2015); Sarah Binder and Mark Spindel, The Myth of Independence: How Congress Governs the Federal Reserve (2017). 
the economy. At the right side of the horizontal axis, we have a recessionary economy. In that economy, the private sector tends to be pessimistic; therefore, it does not actively seek new business opportunities. It refrains from borrowing and deleverages, sheds off debt, because it expects that the worst is yet to come. At the left side of the horizontal axis, we have a booming economy. In a booming economy, the private sector is eager to explore new opportunities by leveraging, taking on more credit.

The vertical axis summarizes the policies prescribed by the FA. The FA may be running a budget deficit or surplus or a balanced budget. A large fiscal deficit denotes fiscal largesse. A government will spend more than what it collects in taxes if it wishes to finance infrastructure projects, support education and welfare programs or fund current consumption. Small deficits, balanced budgets and surpluses, on the other hand, are demonstrative of fiscal restraint.

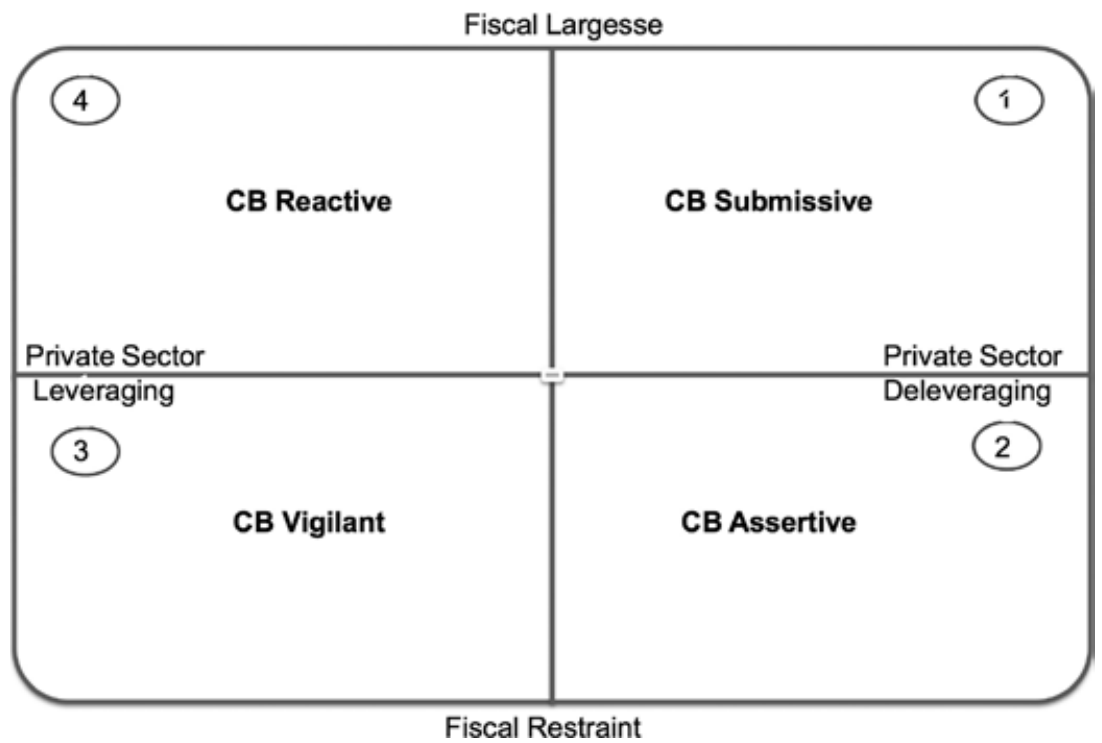

Figure 1.11 The four scenarios: CB posture towards fiscal policy and private leverage/deleverage

\subsubsection{Economic Downturns (Scenarios 1, 2)}

A government cannot always address a budget deficit through more taxation. When the economy is in bad shape, owing to a financial crisis, a trade conflict or an imminent war, a tax increase will trigger more pessimism and depress the economy even further. When the economy suffers, the private sector, businesses and households hoard money instead of investing and spending. Banks 
start charging higher IRs on the loans they give because of the anticipated high default rates. Citizens try to deleverage, pay down their debt, and accumulate savings to ensure that they have enough to survive an uncertain and austere future. Under these circumstances, Kyber has two options (Fig. 1.11).

\subsubsection{Scenario 1: submissive central bank}

To stimulate a deflationary economy, Kyber runs a budget deficit. The FA cuts taxes and increases spending to jumpstart the economy. In dire circumstances, the government is the spender and investor of last resort. It spends to restore the public infrastructure. In this way it employs people who are unemployed, because of the businesses that were destroyed, acting as the employer of last resort. In addition, the government hires private businesses for public works and subsidizes others that are crucial for the functioning of the economy but have suffered losses.

The government plans to finance the ensuing budget deficit by borrowing from the public. It realizes, though, that an already pessimistic public will be unwilling to buy all of the debt it issues. Some of the debt, therefore, is bought by its own bank, the CB. Given the dire economic circumstances, the $\mathrm{CB}$ is more than willing to conduct a loose policy and become the lender of last resort to its own government. When the economy is hit by deflation, and the FA takes action to reverse the economic downturn, the $\mathrm{CB}$ finances budget deficits as needed. The CB is submissive (Fig. 1.11); it gives in to the expansionary plans of the FA. It supports the FA so that the economy can grow again.

\subsubsection{Scenario 2: assertive central bank}

In scenario 2, the government is unable to run a large budget deficit even when the economy is in recession. Avoiding fiscal deficits during economic downturns is known as austerity. The government, instead of increasing spending and cutting taxes to stimulate the economy, hikes taxes and reduces spending by curtailing essential social services. Governments that opt for austerity in tough times tend to be concerned about inflation. In our example, the many inflationary episodes in Kyber's history have made people aware that the money it prints, if printed excessively, can lose all of its value. The public is convinced that government debt and, even worse, the monetization of such debt by the $\mathrm{CB}$, causes inflation and often hyperinflation.

To assuage peoples' fears the government must run a balanced budget or surplus. In fact, the obligation of the government to keep a balanced budget or, at least, to maintain a budget deficit of $3 \%$ of GDP, has been enshrined in the supreme law of the land, the constitution. In addition, a group of citizens, who 
call themselves 'bond market vigilantes', ${ }^{22}$ tend to actively protest loose fiscal policies. They do so by selling off government bonds, when they determine that government debt is excessive. Those sell-offs trigger sharp declines in bond prices and the skyrocketing of bond yields (see Box 1.4). The FA is well aware that the debt it issues is sustainable until bond yields rise to the point of making it unsustainable. Since the FA has tied its own hands and is constricted by private actors, the $\mathrm{CB}$ is the only authority that can act.

The CB has many tools at its disposal. It can reduce the benchmark IR to zero or even introduce negative IRs. ${ }^{23}$ Low IRs are good for debtors and should entice people and business to borrow, expanding the MS. The CB, because of its role as lender of last resort, may also lend money to private banks in exchange for even bad quality collateral. ${ }^{24}$ The $\mathrm{CB}$ can finance corporations directly by buying their bonds. It can employ other unconventional monetary measures such as buying corporate stocks. In other words, when the FA is unable to take initiative, the CB becomes assertive (Fig. 1.11). It takes initiative to get the economy out of the slump.

It is unclear, though, whether CB's intervention will be sufficient to save the economy. If the private sector refuses to borrow, despite the low rates, CB's stimulus will remain trapped in the banking system. If businesses are not lured to borrow or banks are too cautious to lend, the CB's monetary expansion will be blocked. As mentioned above, the government, through its FA, is the borrower of last resort. If the government has abrogated that role by inserting in the constitution a clause that restricts fiscal deficits, the $\mathrm{CB}$ can attempt to revive the private sector by lending to private banks or even directly to corporations. After it exhausts those tools, though, the only thing it can do is to hope that the FA will find the will and the way to act.

In conclusion, in both scenarios 1 and 2 (Fig. 1.11), when recessionary forces squeeze the economy, the $\mathrm{CB}$ can deploy tools to stimulate the economy. When the government runs a budget deficit, the role of $\mathrm{CB}$ is somewhat easy: the borrower of last resort, the FA, and lender of the last resort, the $\mathrm{CB}$, work hand-in-hand to revive the economy. The government runs a deficit, to provide employment and rebuild infrastructure, which is financed by its own CB. In scenario 2, though, it seems that the FA and the CB work at cross-purposes. The FA cannot do much because it has pledged not to run excessive deficits.

22 The term was coined in the 1980s by Edward Yardeni. See Edward Yardeni, Predicting the Markets: A Professional Autobiography 19 (2018).

23 On negative IRs, see Chapter 4, Section 4.3.2.

24 See Jean-Pierre Landau, Global Liquidity: Public and Private 223, at 247, in Proceedings of Jackson Hole Economic Policy Symposium on 'Global Dimensions of Unconventional Monetary Policy,' Federal Reserve Bank of Kansas City, Aug. 22-24, 2013. 
The CB then rebels and runs single-handedly an expansionary policy. Such policy will be successful if the private sector is eager to borrow the money the $\mathrm{CB}$ creates. If the private sector remains pessimistic about the economy, the CB's expansionary policy will be derailed. Eventually the FA may have to exploit some of the ambiguities in the legal rules to proactively engage with the CB.

\subsubsection{Economic Upturns (Scenarios 3, 4)}

\subsubsection{Scenario 3: vigilant central bank}

Under this scenario, the government runs a small deficit and inflation fluctuates around $2 \%$. Almost all who wish to be employed are able to find jobs. Private credit may be moderate to high as people borrow to start businesses or buy homes. Because the fiscal policy is conservative, the $\mathrm{CB}$ refrains from actively intervening in the economy. The CB remains vigilant (Fig. 1.11), however, watching especially the growth of private credit, which could become unsustainable. Too much credit may trigger high inflation and asset bubbles.

\subsubsection{Scenario 4: reactive central bank}

In this scenario, inflation gets out of hand, exceeding the $2 \%$ target rate that the $\mathrm{CB}$ has set. People are irrationally exuberant, believing that prosperity can last forever. A technological breakthrough has generated beliefs that businesses will reap significant benefits from productivity gains and has propelled a buying frenzy in the stockmarket. The CB knows that excessive optimism in a booming economy can cause asset bubbles. Moreover, the FA is running a large budget deficit, adding more fuel to an already overheated economy.

Under these circumstances, the CB has to pull the reins in on the economy to keep it growing at a sustainable rate. It can do this by pursuing a tight policy, for instance, by hiking the benchmark IR to slow down the economy. A drastic increase of the benchmark IR, from 3 to $20 \%$, for instance, can convince people to start saving instead of spending. A $20 \%$ IR can also reduce speculation in the stockmarket, as people will think twice before buying stocks on margin, i.e. borrowing to purchase stocks. A high IR should cool down an overheated housing market. People would hesitate to buy a house when they have to pay a $20 \%$ IR (plus the risk premium) on their loan.

A reactive $\mathrm{CB}$ that tries to discipline an $\mathrm{FA}$ that runs a large budget deficit (Fig. 1.11) makes the government look incoherent. The FA and the $\mathrm{CB}$ seem to work at cross-purposes when the $\mathrm{CB}$ raises the benchmark IR, to encourage people to save and fight inflation, while the FA cuts taxes, to give people more income, and fuels inflationary growth. Because of the CB's reactive stance, the FA will be hurt by the high IRs that would make it more difficult to finance government deficits. Unfortunately for the FA, it cannot instruct the $\mathrm{CB}$ to 
lower IRs. The independence of the CB, even if not enshrined in the constitution, is highly respected. The FA will have, therefore, to reduce its deficit, eventually. The CB, because of its independence, has the clout to restrain its own government. The independence of the $\mathrm{CB}$, if respected, can help Kyber preserve the value of its currency and avoid potential economic pitfalls that can undermine its global reign. 